$\begin{array}{ll}\text { Abstracta Iranica } & \begin{array}{l}\text { Abstracta Iranica } \\ \text { Revue bibliographique pour le domaine irano-aryen }\end{array} \\ & \text { Volume } \mathbf{3 1} \mid \mathbf{2 0 1 1} \\ & \text { Comptes rendus des publications de } \mathbf{2 0 0 8}\end{array}$

\title{
« Glass trade in the Persian Period: The evidence from Palestine ». Trans. 36, 2008, p. 79-90.
}

\section{Astrid Nunn}

\section{(2) OpenEdition}

1 Journals

Édition électronique

URL : http://journals.openedition.org/abstractairanica/39181

DOI : 10.4000/abstractairanica.39181

ISSN : 1961-960X

Éditeur :

CNRS (UMR 7528 Mondes iraniens et indiens), Éditions de l'IFRI

\section{Édition imprimée}

Date de publication : 15 mai 2011

ISSN : 0240-8910

\section{Référence électronique}

Astrid Nunn, « «Glass trade in the Persian Period: The evidence from Palestine ». Trans. 36, 2008, p. 79-90. », Abstracta Iranica [En ligne], Volume 31 | 2011, document 46, mis en ligne le 15 février 2012, consulté le 05 octobre 2020. URL : http://journals.openedition.org/abstractairanica/39181 ; DOI : https://doi.org/10.4000/abstractairanica.39181

Ce document a été généré automatiquement le 5 octobre 2020.

Tous droits réservés 


\title{
" Glass trade in the Persian Period: The evidence from Palestine $»$.
} Trans. 36, 2008, p. 79-90.

\author{
Astrid Nunn
}

1 L'A. décrit et analyse les vaisselles et les objets de verre datant de l'époque perse et découverts en Israël/Palestine lors de fouilles archéologiques de sites en grande majorité côtiers. Le catalogue consiste en 40 petits vases (amphorisques, œnochoés, alabastres) fabriqués selon la technique du noyau de sable et déposés dans des tombes ou retrouvés dans des maisons. Un seul exemple fabriqué en verre moulé a été retrouvé, cette fois-ci, dans une tombe d'Atlit. Un autre groupe d'objets en verre consiste en 18 amulettes et pendentifs en forme d'oeil et de tête ainsi qu'en 11 sceaux coniques, scaraboïdes ou ovales. Le verre est un produit de luxe qui néanmoins, vu le nombre d'objets, devait à l'époque achéménide être accessible à une couche plus large. Les très nombreuses trouvailles de Rhodes laissent supposer que cette île était, outre la Phénicie, un centre important de production. Mais certains ateliers devaient aussi se trouver en Palestine.

\section{INDEX}

Thèmes : 3.2.2. Pré-Achéménides et Achéménides 


\section{AUTEURS}

\section{ASTRID NUNN}

Université de Munich 